\title{
Shelf life of rainbow trout fillets hot smoking with different sauces
}

\section{Farklı soslarla sıcak tütsülenmiş gökkuşağı alabalıklarının raf ömrü}

\author{
Ayşe Gürel İnanlı* (D) • Nermin Karaton Kuzgun ${ }^{2}$ (D) Özlem Emir Çoban ${ }^{1}$ (D) • Emine Özpolat ${ }^{1}$
}

${ }^{1}$ Fisheries Faculty, Fırat University Elazı̆̆, Turkey

${ }^{2}$ Fisheries Faculty, Munzur University Tunceli, Turkey

${ }^{*}$ Corresponding author: aginanli@firat.edu.tr

How to cite this paper:

Gürel İnanlı, A., Kuzgun, N., Emir Çoban, Ö. \& Özpolat, E. (2018). Shelf life of rainbow trout fillets hot smoking with different sauces. Ege Journal of Fisheries and Aquatic Sciences, 35(1): 43-48. doi:10.12714/egejfas.2018.35.1.08

\begin{abstract}
In this study, products of smoked fish were prepared from rainbow trout (Oncorhynchus mykiss, Walbaum 1792). Smoked fish with different sauce were prepared by targeting an increase in the consumption of trout which has a considerable production potential and is a delicious fish. 4 groups (A, B, C and D) applied with different sauces were prepared in the study. Samples were stored in a refrigerator $\left(4^{\circ} \mathrm{C}\right)$ during storage. The aim of the study is to determine the chemical, microbiological and sensorial changes, the shelf life of products during the storage period of products. Study had 2 replicates and analyses had 3 parallels. As a result, the qualities of chemical, microbiological and sensorial of the smoked samples prepared in our study were examined. The evaluation of data showed the shelf life as 14 days for $A, 28$ days for $B, 21$ days for $C$ and 35 days for $D$ with sauces. When the data obtained were evaluated, the shelf life was determined as 14 days for $A, 28$ days for $B, 21$ days for $C$ and 35 days for $D$ with sauces.
\end{abstract}

Keywords: Rainbow trout, smoked, different sauce, shelf life

Öz: Çalışmada, gökkuşağı alabalıklarından (Oncorhynchus mykiss, Walbaum 1792) füme ürünler hazırlanmıştır. Farklı soslar ilave edilen füme balıklar, önemli miktarda üretim potansiyeli ve lezzetli bir balık olan alabalık tüketiminde bir artışı hedefleyerek hazırlanmıştır. Çalışmada farklı soslar uygulanarak 4 grup (A, B, C ve $\mathrm{D}$ ) elde edilmiştir. Örnekler, muhafaza süresince buzdolabı koșullarında $\left(+4^{\circ} \mathrm{C}\right)$ muhafazaya alınmış̦tır. Bu araşıırmada, ürünlerin muhafaza kalitesini ve raf ömrünü etkileyen kimyasal değişikliklerin belirlenmesi amaçlanmıştır. Çalışma 2 tekerrürlü ve analizler 3 paralelli olarak yapılmıştır.

Sonuç olarak, çalışmamızda hazırlanan tütsülenmiş örneklerin, kimyasal, mikrobiyolojik ve duyusal özellikleri belirlenmiştir. Elde edilen veriler değerlendirildiğinde örneklerin raf ömrü, A grubu için 14 gün, B grubu için 28 gün, C grubu için 21 gün ve D grubu için 35 gün olarak belirlenmiştir.

Anahtar kelimeler: Gökkuşağı alabalığı, tütsüleme, farklı sos, raf ömrü

\section{INTRODUCTION}

Smoking of food products for storage is one of the oldest known food storage methods. It is applied to all kinds of meat and meat products, cheese and seafood including the crustaceans (Stolyhwo and Sikorski, 2005). Previously performed solely for protecting the product, smoking now also aims at offering the product to the consumers in different forms by changing the taste of the product (Varlet et al., 2007). The smoking process preserves fish by means of the synergistic action of different factors, such as salt incorporation. The principle of storage through smoking is to remove a certain part of the water that the fish contains and to prevent the development of microorganisms by ensuring the passage of bactericides in the smoke into the fish. These changes delay the microbiological and oxidative changes that lead to spoilage, extending the shelf-life of the processed fish (Cornu et al., 2006; Rizo et al., 2015). One of the processing technologies applied on the fish is smoking. Smoking technology and consumption of smoked products developed and became widespread in Japan and other Far Eastern countries, Canada, European Union (EU) countries and Scandinavian countries. In our country, consumption of smoked products is rather uncommon when compared to other countries and some enterprises perform smoking by using this technology and sell these products to foreign countries (Bilgin et al., 2007).

Rainbow trout (Oncorhynchus mykiss, Walbaum 1792), which is the most commonly farmed species in our country, is a delicious fish. Thus, this highly favored species is subjected to freezing or smoking processes in addition to fresh consumption.

In this study, differently sauced smoked fish were prepared by targeting an increase in the consumption of trout which has a considerable production potential and is a delicious fish. The impacts of the sauces used on the shelf life were studied by examining the chemical, microbiological and sensorial changes of these products. 


\section{MATERIALS AND METHODS}

\section{Fish material and treatments}

The experimental material consisted of farmed rainbow trout (Oncorhynchus mykiss) weighing $1.0 \mathrm{~kg}$. After slaughter (gill cut and bleeding) fishes were eviscerated, cleaned and placed on ice (ice/fish, 1/3) into the strafor boxes and transported $\left(4^{\circ} \mathrm{C}\right)$ to the laboratory in one hour period. Study had 2 replicates and analyses had 3 parallels.

\section{Preparation of smoked fish and storage conditions}

Fish were processed as smoked. all fish were filleted and by hand to remove skin, bones, fins and visible adipose tissue In this study, flow diagram of the production of smoked fish is shown in Figure 1.

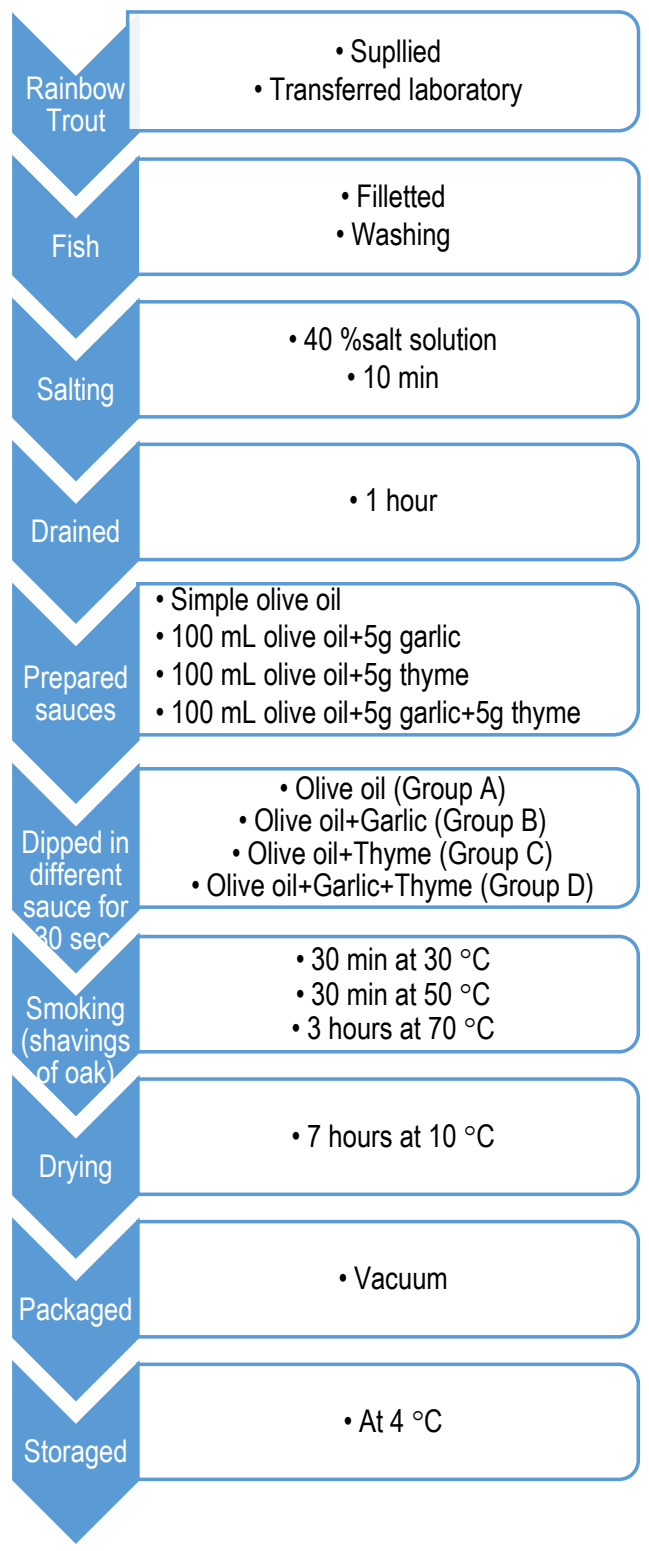

Figure 1. The flow diagram of smoked trout filets with different sauces

\section{Chemical analyses}

$\mathrm{pH}$ value of the samples was measured with a digital electronic $\mathrm{pH}$ meter (Thermo Scientific Orion 3-Star Benchtop, Cambridge, UK) (AOAC, 2002). TVB-N amounts in the products produced for the study were determined by the method reported by Varlik et al. (1993). TBA value was determined as described by Tarladgis et al. (1960). $10 \mathrm{~g}$ homogenized samples were washed into the distillation flask and $2 \mathrm{~g}$ magnesium oxide and a drop or two of antifoam solution were added. The contents were boiled and distilled into $10 \mathrm{ml}$ of 3 percent boric acid solution with added indicator in a $500 \mathrm{ml}$ conical flask. After distillation, contents of the conical flask were titrated with $0.1 \mathrm{~N} \mathrm{HCl}$ (Schormüller, 1968).

\section{Microbiological analyses}

Each sample was first treated as follows: a sample (10 g) was taken from each fish fillet, placed aseptically into a stomacher bag (Seward Medical, Worthing, UK) containing 90 $\mathrm{mL}$ of $0.1 \%$ buffer peptone water, and the mixture was homogenized for $60 \mathrm{~s}$ using a Stomacher (Lab Blender 400, London, U.K.) at room temperature. For microbial enumeration, $0.1 \mathrm{~mL}$ samples of serially dilutions (1:10, diluent, $0.1 \%$ peptone water) of fish homogenates was spread onto plates of various agar materials. Total aerobic mesophiles was determined using plate count agar (PCA, Oxoid, CM325) after incubation at $30^{\circ} \mathrm{C}$ for $72 \mathrm{~h}$. Aerobic pychrophiles was counted using plate count agar (PCA, Merck 1.05463, Merck, KgaA Darmstat, Germany) after incubation for 7-10 days at $5{ }^{\circ} \mathrm{C}$. Yeast and mold counts were determined using Potato Dextrose agar (PDA, Merck 1.10130). Yeast and mold were incubated at $22{ }^{\circ} \mathrm{C}$ for $3-5$ days. All colonies were counted and the data were reported as colony forming units (log cfu g-1 ) (Harrigan, 1998).

\section{Sensorial evaluation}

The attributes of trout (odor, color, appearance and overall acceptability) were evaluated by a panel of seven experienced panelists in the analysis days of sampling. Sensory evaluation was conducted in individual booths under controlled conditions of light, temperature and humidity. Sensory analysis was performed using the methods of (Altuğ Onoğur and Elmacı, 2011).

Panelists were asked to evaluate on a 5-point hedonic scale ranging from very poor (1) to very good (5) where: 1 very poor, 2 - poor, 3 - normal, 4 - good and 5 - very good.

\section{Statistical analysis}

All measurements were accomplished in triplicate and the results are given as the mean and standard deviation. A oneway variance analysis (ANOVA) was applied by using the IBMSPSS ${ }^{\circledR} 22$ version software (Chicago, Illinois, USA) and the Duncan's Multiple Range Test comparisons at $P$ value of $<0.05$ were carried out to indicate significant differences (Özdamar, 2001). 


\section{RESULTS AND DISCUSSION}

Chemical, microbiological and sensory changes of the rainbow trout fillets smoked with different sauces during the storage are shown in Figure 2-3-4.

\section{Chemical changes}

In all groups of rainbow trout fillets smoked with different sauces during storage, $\mathrm{pH}$ values decreased at the beginning while different changes were observed in the subsequent days of the storage (Figure 2). In group A, pH value, which was 6.92, increased to 7.12 at the end of the storage. In group $\mathrm{B}, \mathrm{pH}$ value, which was 6.84 at the beginning, continued declining during the storage and rose to 7.05 at the $35^{\text {th }}$ day when spoilage was detected. In group $\mathrm{C}$, pH value, which was 6.84 at the outset, did not change much in time and was determined as 6.92 at the $28^{\text {th }}$ day. Also difference between $\mathrm{pH}$ values during storage determined relative to groups in the study was not found statistically significant ( $p>0.05)$. In group $D, p H$ value, which was 6.90, first decreased and then increased to 7.20. It is reported that $\mathrm{pH}$ value increases during storage of the products, and this results from trimethylamine, ammoniac and other nitrous compounds which develop due to microorganism activities (Tokur et al., 2006). In the study conducted with smoked fillets, Ünal (1995) determined that $\mathrm{pH}$ value changed between 6.05 and 6.26 in the sample stored in fridge conditions. These values confirm that the changes in the $\mathrm{pH}$ values of the rainbow trout fillet samples, which were smoked with different sauces and stored at $4 \pm 0.5^{\circ} \mathrm{C}$, are not significant. Bilgin et al. (2007) reported that the $\mathrm{pH}$ value of $S$. trutta macrostigma samples which were hot smoked and stored at 4.0 $\pm 0.5^{\circ} \mathrm{C}$ was $6.290 \pm 0.010$ at the end of storage. This value is similar to the values found in this study.

As to the TVB-N values of the smoked sauced trout fillets, it was detected that increases occurred when compared to the initial values and, as the highest increase, the sample with the sauce $D$ reached $33.54 \mathrm{mg} / 100 \mathrm{~g}$ at the $42^{\text {nd }}$ day. The group with the sauce A spoiled at the end of the 21 st day and TVB-N value was determined as $33.32 \mathrm{mg} / 100 \mathrm{~g}$. Group B spoiled at the end of the $35^{\text {th }}$ day with TVB-N value of $34.25 \mathrm{mg} / 100 \mathrm{~g}$ while the group with the sauce $C$ spoiled at the $28^{\text {th }}$ day with a TVB-N value of $33.21 \mathrm{mg} / 100 \mathrm{~g}$ (Figure 2). Also difference between the TVB-N values during storage determined within groups in the study was found statistically significant $(p<0.05)$. It was reported that the TVB-N value can increase in smoked fish during storage and fish cannot be consumed when it TVB$\mathrm{N}$ value exceeds $35 \mathrm{mg}$ (Varlık et al., 1993). Bilgin et al. (2007) reported that the TVB-N values of the fillets changed within a range from 13.968 to $34.378 \mathrm{mg} / 100 \mathrm{~g}$ during the storage period. These values show similarity to our values.

As for the TBA value which is the measure of rancidity and emerges due to the oxidation of fats in fisheries, 1-3 mg MA kg1 is defined as good quality while the range of $3-8 \mathrm{mg} \mathrm{MA} \mathrm{kg}^{-1}$ is defined as low quality. When it reaches $8 \mathrm{mg} \mathrm{MA} \mathrm{kg}^{-1}$, the product is defined as inconsumable (Köse and Erdem, 2001; Varlık et al., 2000). When TBA values were examined in our study, while TBA values differed from 1.67 to $2.26 \mathrm{mg} \mathrm{MA} \mathrm{kg}^{-1}$ in all groups at the beginning, they changed slightly during the storage period and TBA values were determined as $3.85 \mathrm{mg}$ $M A ~ ~ k g^{-1}$ at the $21^{\text {st }}$ day for the group A, $3.26 \mathrm{mg} \mathrm{MA} \mathrm{kg}^{-1}$ at the $35^{\text {th }}$ day for the group $B, 2.60 \mathrm{mg} \mathrm{MA} \mathrm{kg}^{-1}$ at the $28^{\text {th }}$ day for the group $C$ and $2.52 \mathrm{mg} \mathrm{MA} \mathrm{kg}^{-1}$ at the $42^{\text {nd }}$ day for the group D, in which the latest spoilage was observed (Figure 2). According to the statistical assessments, difference between the control group and the groups in which sauces were used after the $2^{\text {nd }}$ week was significant $(p<0.05)$. In the groups where the sauce contained thyme, TBA values increased less than the other groups. This result can be explained with the antioxidant nature of thyme. Ünlüsayın et al. (2003) reported that the TBA values of $C$. auratus which were hot smoked and stored for 28 days at $4^{\circ} \mathrm{C}$, increased. These results are parallel to our values. Salama and Khalafalla (1993) conducted a study on conger eel $(A$. vulgaris) and used two different salt concentrations as $7.5 \%$ and $15 \%$. They examined the changes during storage after the samples were smoked. They reported that the TBA values displayed irregular changes and that the samples with higher salt concentrations spoiled less.
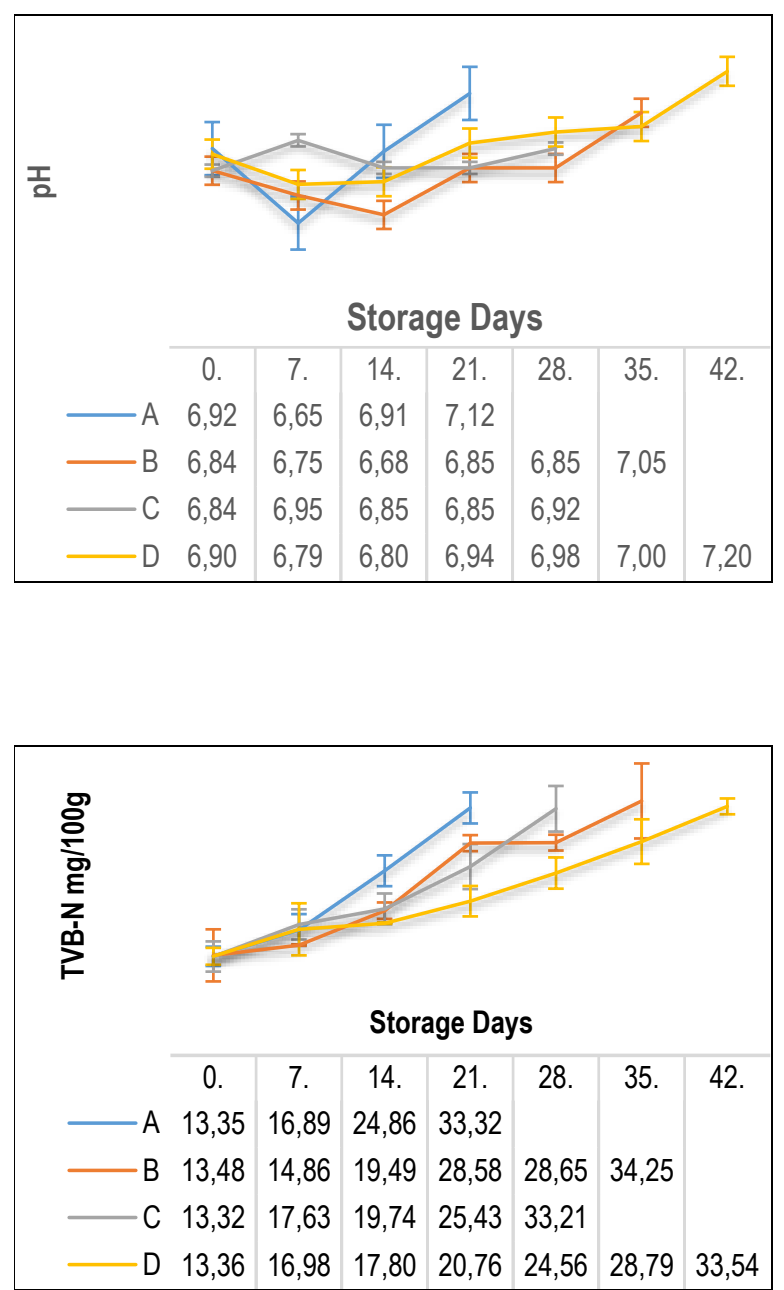


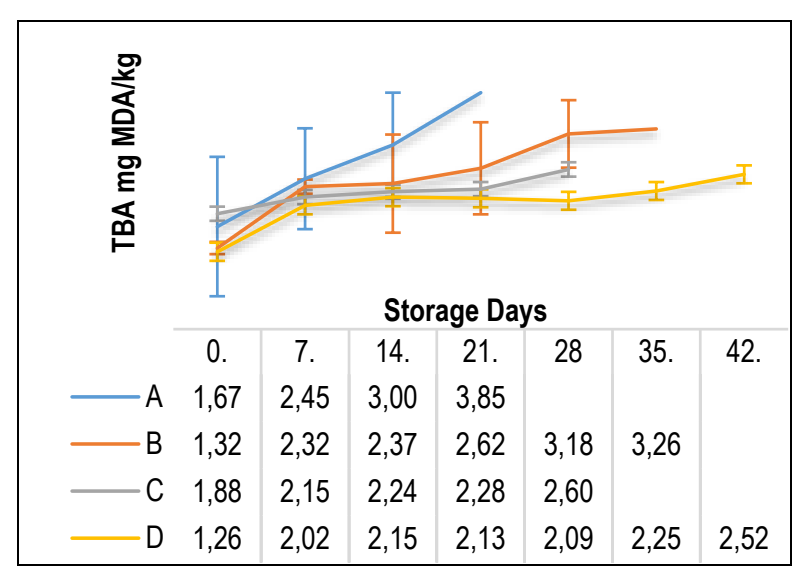

Figure 2. The chemical changes of smoked rainbow trouts with different sauces

\section{Microbiological determinations}

When microbiological analyses of the trout fillets sauced and smoked in different ways were examined, increases in numbers of mesophile psicrophile bacteria and yeast-mold were observed in all analysis groups depending on the storage duration (Figure 3).

While aerobic mesophiles were $2.10 \log _{\mathrm{cfu}} \mathrm{g}^{-1}$ in group A at the outset, aerobic mesophile numbers were lower in the other groups. At the end of the storage period, aerobic mesophile numbers increased and reached $5.99 \log \mathrm{cfu} \mathrm{g}^{-1}$, $5.45 \log _{\text {cfu g }}{ }^{-1}, 4.44 \log _{\text {cfu g }}{ }^{-1}$ and $5.23 \log _{\text {cfu g }} \mathrm{g}^{-1}$ in group A, group $B$, group $C$ and group $D$, respectively. In the control group, the differences among the storage days were found significant $(p<0.05)$. Although aerobic mesophile numbers increased in the groups where sauces were used during the storage, these increases were not as high as in the control group (Figure 3). The differences between the control group and the groups where sauces were used was found to be statistically significant $(p<0.05)$ while the difference between group $C$ and group $D$ at the $28^{\text {th }}$ day was found significant $(p<0.05)$. Dondero et al. $(2004)$ reported that increases in aerobic mesophile numbers were associated with storage duration and temperature. Kolsarıcı and Özkaya (1998) reported that aerobic mesophile number of hot smoked trout samples was $4.32 \log _{\text {cfu }} \mathrm{g}^{-1}$ at the beginning of the storage while it was determined as $7.36 \operatorname{log~cfu~g}^{-1}$ at the end of storage at $+4 \pm 1^{\circ} \mathrm{C}$. These values are similar to our findings. Schulze (1985) reported that aerobic psychrophile number increased depending on the storage duration in trout samples which were smoked in whole and as fillets and stored at $4^{\circ} \mathrm{C}$ and $10^{\circ} \mathrm{C}$.

The number of psychrotrophic bacteria can increase in the food products stored in the fridge conditions and may lead to food-related diseases. Some researchers have reported that there are pathogens frequently encountered in the smoked products stored in fridge conditions. In this study, it was determined that the aerobic psychrophile number was far below the limit value of $6 \log$ cfu $\mathrm{g}^{-1}$. The number of psychrotrophic bacteria, which was $1 \log _{\text {cfu }} \mathrm{g}^{-1}$ at the beginning, did not show statistically significant differences among the groups and the storage days until the $14^{\text {th }}$ day of the storage (Figure 3 ). At the $21^{\text {st }}$ day of the storage, statistically significant differences were observed between the control group and the groups where thyme and garlic were added $(p<0.05)$. In the control group, differences were observed between the $21^{\text {st }}$ day and the other days. In the groups where the sauce contained thyme, differences of the days following the $21^{\text {st }}$ day were significant. Deng et al. (1974) reported that aerobic psychrophile numbers in the smoked fish might increase slightly during storage.

When yeast and mold values were examined, while they

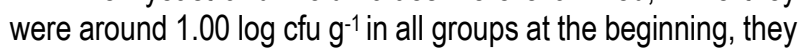
displayed slight increases in time. At the end of storage, they were determined as $1.65 \operatorname{log~cfu~g}^{-1} ; 1.69 \log _{\text {cfu g }}{ }^{-1} ; 1.65 \mathrm{log}$ cfu $\mathrm{g}^{-1}$; and $2.15 \log$ cfu $^{-1}$ in group $A$, group $B$, group $C$ and group $D$ where the latest spoilage was observed (Figure 3 ). Dondero et al. (2004) reported that yeast and mold values might increase slightly.
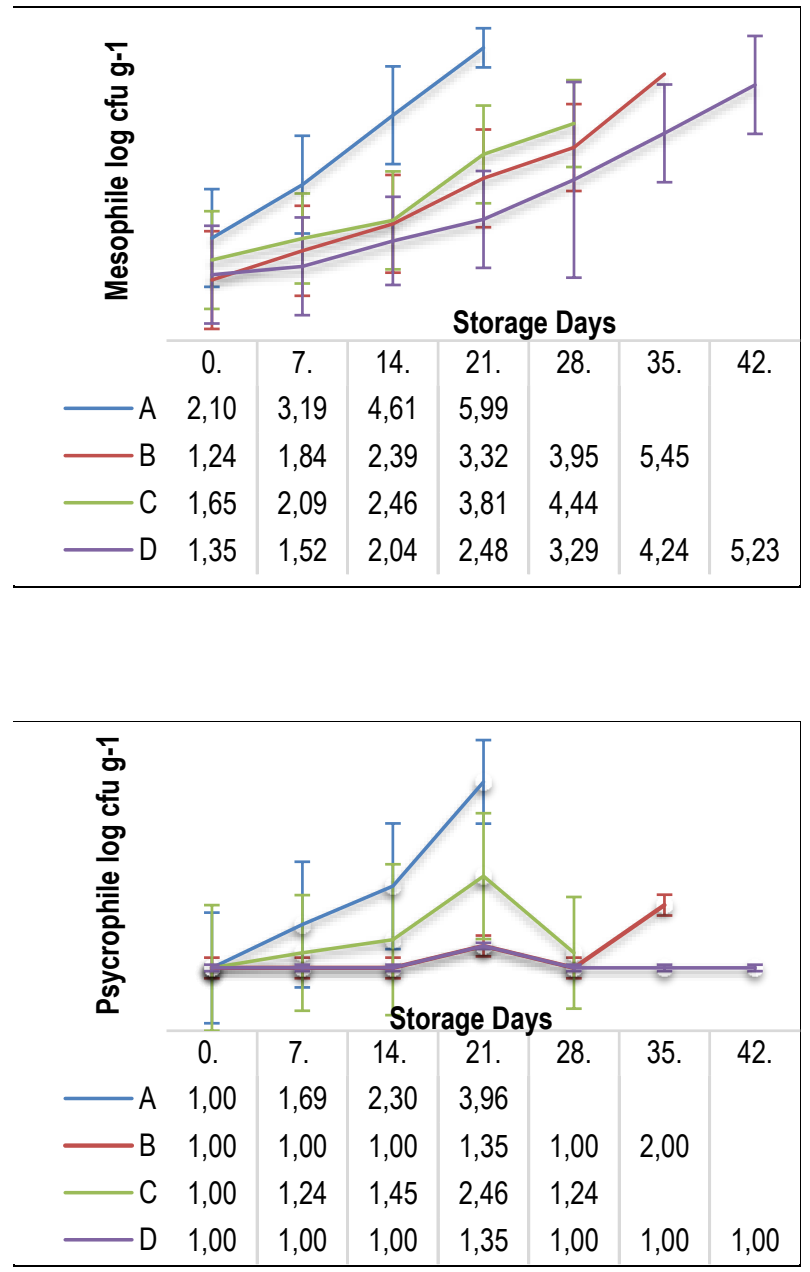


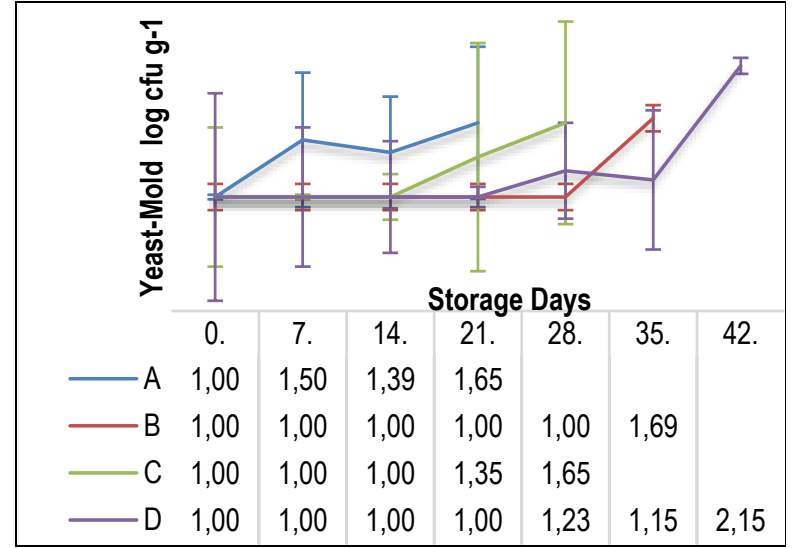

Figure 3. The microbiological changes of smoked rainbow trouts with different sauces

A: Olive oil B: Olive oil + Garlic C: Olive oil + Thyme D: Olive oil + Garlic + Thyme

\section{Sensory evaluation}

Rainbow trout fillets, which were smoked with different sauces, were assessed in terms of sensory changes during the storage period such as taste, smell and general acceptability and were scored between 1 and 5 , and it was determined that they are highly popular products. After all sensory assessments, it was concluded that the samples of the group
$D$ were liked at most $(p<0.01)$. The least favorite ones were the samples of the group A (Figure 4). Results of the sensory assessments conducted by Deng et al. (1974), Gökoğlu and Varlık (1992) and Kolsarıcı and Özkaya (1998) on the smoked fish are consistent with the findings of the present study.

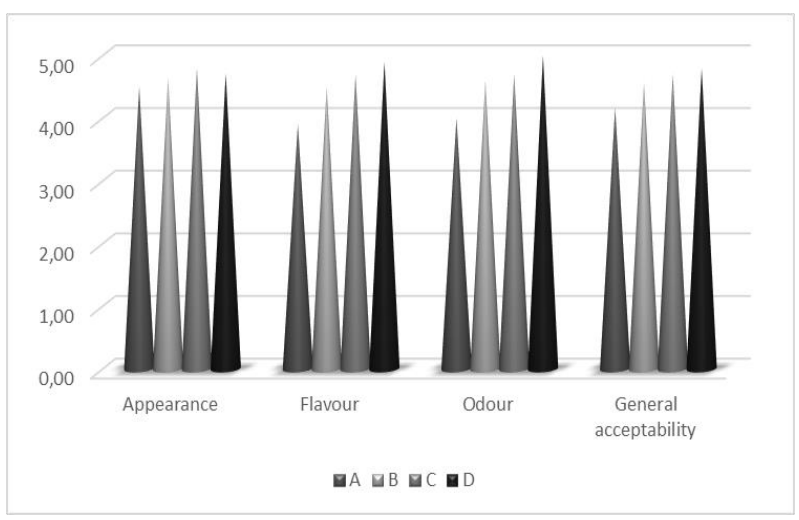

Figure 4. Sensory changes of samples during storage

A: Olive oil B: Olive oil + Garlic C: Olive oil + Thyme D: Olive oil + Garlic + Thyme

As a result, the qualities of chemical, microbiological and sensorial of the smoked samples prepared in our study were examined. When the data obtained were evaluated, the shelf life was determined as 14 days for $A, 28$ days for $B, 21$ days for $C$ and 35 days for $D$ with sauces.

\section{REFERENCES}

Altuğ Onoğur, T. \& Elmacı, Y. (2011). Sensorial Evaluation on Foods. Sidas Publishing, İmir

AOAC. (2002). Official Metods of Analysis of The Association of Official Analytical Chemists (17 th ed.) Association of Official Analytical Chemists. Gaithersburg, Maryland.

Bilgin, S., Ertan, Ö. O. \& İzci L. (2007). Investigation on changes in the chemical composition of hot smoked Salmo trutta macrostigma, Dumeril 1858, stored different temperatures Journal of FisheriesSciences.com, 1 (2):6880. doi: 10.17693/yunusae.v16i21960.235781

Cornu, M., Beaufort, A., Rudelle, S., Laloux, L., Bergis, H., Miconnet, N., Serot, T. \& Delignette-Muller, M.L. (2006). Effect of temperature, water-phase salt and phenolic contents on Listeria monocytogenes growth rates on cold-smoked salmon and evaluation of secondary models. Int. J. Food Microbiol. 106: 159-168. doi: 10.1016/j.ijfoodmicro.2005.06.017

Deng, J., Toledo, R.T. \& Lillard, D. (1974). Effect of smoking temperatures on acceptability and storage stability of smoked spanish mackerel. Journal of Food Science; 39: 596-601. doi:10.1111/j.1365-2621.1974.tb02957.x

Dondero, M., Cisternas, F., Carvajal, L., Simpson, R. (2004). Changes in quality of vacuum-packed cold-smoked salmon (Salmo salar) as a function of storage temperature. Food Chemistry, 87,4:5543-550. doi: 10.1016/j.foodchem.2004.01.005

Gökoglu, N. \& Varlık, C. (1992). The Research on Shelf-Life of Smoked Rainbow Trout (Salmo gairdneri), Journal of Food. 17, 1: 61-65

Harrigan WF. (1998). Laboratory Methods in Food Microbiology. 3rd ed. Academic Press. London.

Kolsarıcı, N. \& Özkaya Ö. (1998). Effect of Smoking Methods on Shelf-Life of Rainbow Trout (Salmo gairdneri). Veterinary and Animal Sicences, 22 273-284.

Köse, S. \& Erdem, M.E. (2001). Quality changes of whiting (Merlangius merlangus euxinus, N. 1840) stored at ambient and refrigerated temperatures. Turkish Journal of Aquatic Sciences, 1: 59-65.

Özdamar, K. (2001). Biostatistical with SPSS.. Pub no: 3,4. Bookstore Kaan. Eskişehir, p:452.

Rizo, A., Manes, V., Fuentes, A., Fernandez-Segovia I. \& Barat, J. M. (2015). Physicochemical and microbial changes during storage of smokeflavoured salmon obtained by a new method. Food Control, 56: 195-201. doi:10.1016/j.foodcont.2015.03.030

Salama NA, Khalafalla GM. (1993). Chemical, bacteriological and sensory changes in eel fish (Anguilla vulgaris) during smoking and storage. Archiv für Lebensmittelhygiene, 44, 1-24 pp.

Schormüller, J. (1968). Handbuch der lebensmittel Chemie, Band 11112 Tcil. Tier-ische Lebensmittel Eier. Fleisch. Buttermilch. p. 1400-1401. SpringerVerlag Berlin-Heidelberg-New York.

Schulze, K. (1985). Untersuchungen zur Mikrobiologie, Haltbarkeit und Zusammensetzung von Raucherforellen aus einer Aquakultur. Archiv für Lebensmittelhygiene. 36: 81-85.

Stolyhwo, A. \& Sikorski, Z.E. (2005). Polycyclic Aromatic Hydrocarbons in smoked fish-a critical review. Food Chemistry, 91, 303-311. doi: 10.1016/j.foodchem.2004.06.012

Tarladgis, B.G. Watts, B.M., Younathan M.T. \& Dugan, Jr. (1960). A distillation method for the quantitative determination of malonaldehyde in rancid foods. J. of American Oil Chemist's Soc., 37, 44-48. doi: $10.1007 / B F 02630824$

Tokur B, Öztürk S, Atici E, Özyurt G. \& Özyurt C.E. (2006). Chemical and sensory quality changes of fish fingers, made from mirror carp (Cyprinus 
carpio L., 1758) during frozen storage $\left(-18^{\circ} \mathrm{C}\right)$. Food Chem, $99,335-341$. doi: 10.1016/j.foodchem.2005.07.044

Ünal, G. (1995). A Research on Smoking of Rainbow Trout (Oncorhynchus mykiss W.) and Determination of Quality Criterias it's. Phd. Thesis, Ege University. İzmir.

Ünlüsayın. M. Bilgin, S. İzci, L. (2002). The Determination of meat yield of Poo Fish (Carassius auratus L., 1758), chemical components after hot smoked and shelf life it's. Süleyman Demirel University, Journal of Egirdir Fisheries Faculty, 8: 62-70.
Varlet V.,Prost C. \& Serot T. (2007). Volatile aldehydes in smoked fish: analysis methods, occurence and mechanisms of formation. Food Chemistry, 105:1536-1556. doi:10.1016/j.foodchem.2007.03.041

Varlık, C., Ugur, M., Gokoglu, N. \& Gun, H. (1993). Methods and quality control in seafood product. Food Tech. Publication. No: 17. Istanbul/Turkey.

Varlık, C., Baygar, T., Özden, Ö., Erkan N. \& Metin, S. (2000). Sensory Evaluation and Determination of Some Physical and Chemical Characteristics of Shrimp During Gold Storage. Turkish J. Vet. Anim. Sci., 24: 181-185. 